Journal of Southeast Asian

2014

\title{
The Two Leaders: One Wise and One Foolish
}

Ahmay Ya

Metropolitan State University

Follow this and additional works at: https://docs.lib.purdue.edu/jsaaea

\section{Recommended Citation}

Ya, Ahmay (2014) "The Two Leaders: One Wise and One Foolish," Journal of Southeast Asian American Education and Advancement. Vol. 9 : Iss. 1, Article 7.

DOI: $10.7771 / 2153-8999.1082$

Available at: https://docs.lib.purdue.edu/jsaaea/vol9/iss1/7

This document has been made available through Purdue e-Pubs, a service of the Purdue University Libraries. Please contact epubs@purdue.edu for additional information.

This is an Open Access journal. This means that it uses a funding model that does not charge readers or their institutions for access. Readers may freely read, download, copy, distribute, print, search, or link to the full texts of articles. This journal is covered under the CC BY-NC-ND license. 


\section{Ya: The Two Leaders: One Wise and One Foolish
JSA AEA Journal of Southeast Asian American Education \& Advancement}

Volume 9 (2014)
WWW.JSAAEA.org

\author{
The Two Leaders: One Wise and One Foolish
}

A peer-reviewed

scholarly journal

published by the

National Association

for the Education \&

Advancement of

Cambodian, Laotian,

and Vietnamese

Americans (NAFEA)

\begin{abstract}
By
Ahmay Ya

Retold in English by Ahmay Ya from a story that Moe Moe, her grandmother, had told her when Ahmay was just a small girl in Burma
\end{abstract}

Once upon a time, close to the kingdom of Bayrnathi, there was a village where one thousand carpenters lived. They had lived there happily for a very long time but now they experienced many difficulties such as not enough employment or food, and they were heavily into debt. They decided to leave their village and search for a new location where they could have a better life. So they built a big ship and sailed away, taking their families with them.

One day, far out at sea, they saw a small island. When they arrived on the shores of the small island, they explored the island and found that many different kinds of fruit trees grew there, and there was enough rice and water for everyone. As they wandered around, they met a man who had been shipwrecked on the island long before their arrival. He welcomed the carpenters and said, "Dear friends, there is plenty of food on this island, there are no dangers here, but there is something very important you all need to know about this island. It is guarded by the nats, Sprit Beings. The nats hate to see the garbage that human beings produce every day. If you want to live peacefully here, don't litter. Makes deep holes in the sand, burn and bury your garbage in the holes and after that, make sure you cover the holes up with lots of sand."

The carpenters decided to settle and make their homes on this island. Among the one thousand carpenters were two leaders. One was the leader of five hundred carpenters and the other was the leader of the other five hundred. One of the leaders was wise and the other was foolish.

After they had lived on this island for some time, the foolish leader and his carpenters made alcohol from sugarcane. They were joyful, sang and danced and they kept on drinking. They became so drunk that they no longer cared about their environment. They threw garbage all over the place and they did not bother to burn and bury it.

The irresponsible behavior of these human beings made the nats very angry. The nats agreed on a plan together. "In fifteen days we will cause a tsunami and let the high waves clean the beaches and get rid of these irresponsible people as well." However, among the nats, there was a nat who was especially kind and loving. She did not want the people to die. She appeared on a cloud to warn the carpenters. She advised them to leave the island before the fifteenth day. Unfortunately, soon after she had spoken, a cruel and harmful nat came on another cloud. The cruel nat said, "Don't believe what that nat told you. She said that because she does not like

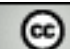

SOMERIGHISRESEREED Readers are free to copy, display, and distribute this article, as long as the work is attributed to the author(s) and the Journal of Southeast Asian American Education \& Advancement, it is distributed for noncommercial purposes only, and no alteration or transformation is made in the work. More details of this Creative Commons license are available at http://creativecommons.org/licenses/by-nc-nd/3.0/. All other uses must be approved by the author(s) or JSAAEA. 
human behavior or human beings. But don't worry, just keep on living and playing here as usual. Remain here, you are not in any danger."

The wise leader thought about what the two nats had said. He called for a meeting with all the carpenters and said, "Friends, I think we should build boats and get ready to leave before any danger comes our way. If the first nat spoke the truth, we will then be able to leave in our boats as soon as the water rises. And if the second nat spoke the truth, we can keep the boats in a safe place and continue to live here as before."

The foolish leader did not agree. He said, "Friend, you just want to make us do more work for nothing. The first nat hates us. We should believe the second nat because she loves us. Why should we leave this beautiful, peaceful island? There's no need to build boats!" Then the foolish leader ordered his five hundred followers not to build boats and they were happy to obey him. They just kept on feasting and drinking and enjoying themselves.

However, the wise leader helped his five hundred carpenters build boats. Then they stocked the boats with food and water. His followers listened to his advice and continued to make all the other preparations necessary for their departure. On the fifteenth day, just as the first nat had warned them, the sea level got higher and higher and the waves flooded the shore. As soon as the people were waist high in water, the wise leader told his followers to get into their boats and sail away from the island.

But the foolish leader and his followers were not disturbed. They said, "Oh, the nats are only cleaning the beach. The water will stop rising after it reaches waist level. It can't go higher than that." However, the sea level didn't stop rising. The waves rose higher and higher and soon the water was up to their shoulders, then up to their heads, then over their heads and finally even covered the tops of the tall coconut trees. The foolish leader and all his followers were drowned.

\section{Notes}

This story was told to Ahmay by her grandmother when Ahmay was a small girl in Burma. Both Ahmay and her grandmother are from the Karen tribe. Ahmay's father is a leader in Burma trying to establish a peaceful life for the Karen. He is working to bring about a ceasefire between the military troops and the ethnic peoples such as Karen, Shan and Kachin. Like the majority of the Karen in Burma, Ahmay and Moe Moe are Buddhist. The story shows how Karen Buddhist traditions were a strong influence in shaping their values. There are deep meanings in this story. The story cautions us to learn the lessons from wise leaders just as the five hundred carpenters listened to their wise leader. Good people pay attention to those who are wise. The story illustrates that one should associate with the wise and not with the foolish. There is also a deep meaning about living in balance and harmony with the earth in a respectful way and not spoiling the environment with our garbage.

Bayrnathi: In this story Bayrnathi refers to a kingdom that may have existed in the time of Buddha over two thousand years ago, Buddha died in about 400 B.C.E.

Karen: the Karen are one of many ethnic minorities in Burma. There are now over ten thousand Karen in Minnesota. The Karen suffered decades of persecution from the Burmese military. 
Nat (spirit): Nats are spirits in Burmese Buddhist beliefs. There are the great nats and there are the lesser spirits of trees, water, mountain, island, ocean, house, school and buildings. Almost all of the 37 Great Nats were human beings who met violent deaths.

About the Author
Ahmay Ya is a bilingual Adult Mental Health Case Manager in Wilder's Southeast Asian
Services. She is earning a social work degree at Metropolitan
State University. "My goal is to become a licensed clinical
social worker in order to serve families and my Karen refugee
community and other ethnic groups from Burma. I will be one
of the first social workers fluent in the Karen and Burmese
languages and cultures and this will help me in helping others
to become better community members and citizens." I am
interested in understanding mental health needs for the Karen
community, an unmet need currently. My hope is to increase
knowledge and insight into this population. I hope to do work
that is not only culturally competent but also culturally
responsive to my community."






Journal of Southeast Asian American Education \& Advancement

Volume 9 (2014)

WWW.JSAAEA.org

\section{Editor}

Dr. Wayne E. Wright

University of Texas at San Antonio

Associate Editors

Dr. Chhany Sak-Humphry

University of Hawaii at Manoa

Dr. Phitsamay Sychitkokhong Uy

University of Massachusetts, Lowell

\section{Book Review Editor}

Dr. Vichet Chhuon

University of Minnesota

\section{Creative Works Editor}

Bryan Thao Worra

Lao Assistance Center

Special Advisor

Gregory Green

Curator, Echols Collection on Southeast Asia, Cornell University Library

\section{Journal Manager}

Yeng Yang

University of Texas at San Antonio

\section{Editorial Assistant}

Matthew Kraft

University of Texas at San Antonio
A peer-reviewed

scholarly journal

published by the

National Association

for the Education \&

Advancement of

Cambodian, Laotian,

and Vietnamese

Americans (NAFEA) 


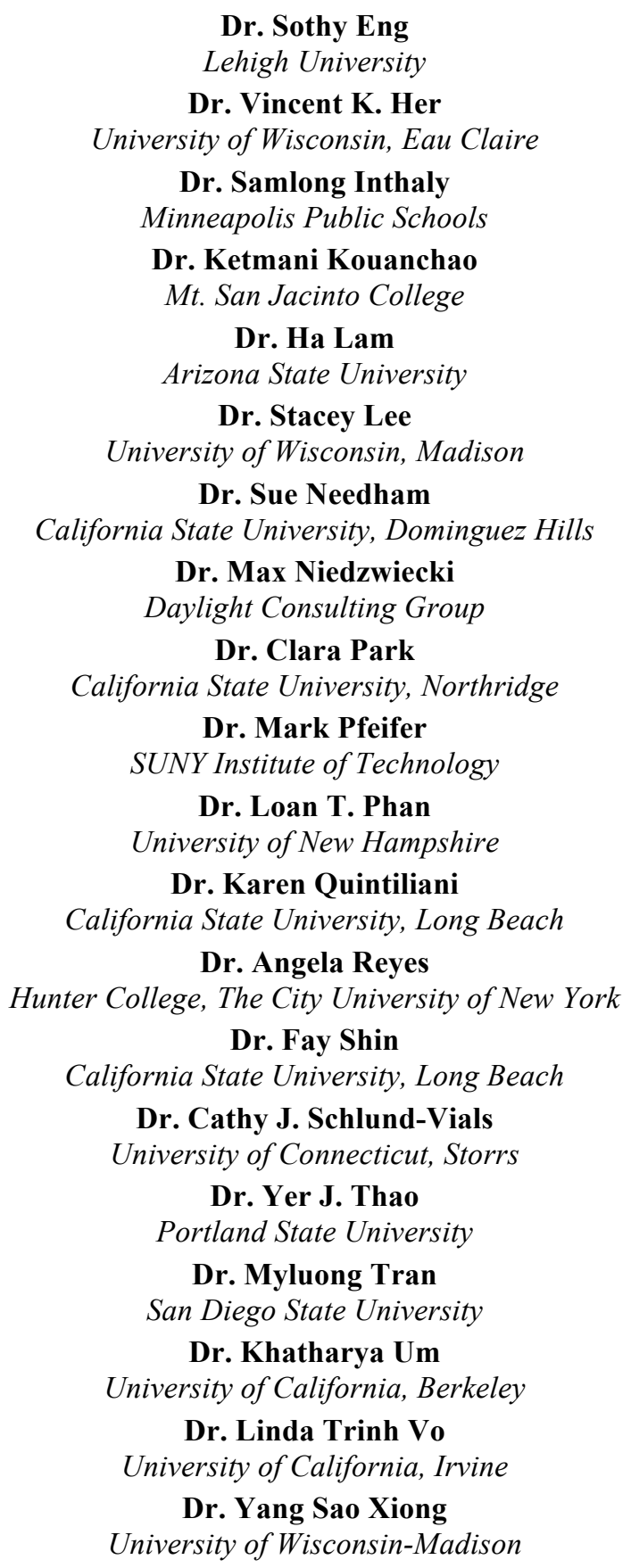

\section{Doctoral Student Editorial Review Board}

Sovicheth Boun

University of Texas at San Antonio

Keo Chea-Young

University of Pennsylvania

Dung Mao

University of Minnesota
Dr. Jeremy Hein

University of Wisconsin, Eau Claire

Dr. Nancy H. Hornberger

University of Pennsylvania

Dr. Peter Nien-Chu Kiang

University of Massachusetts, Boston

Dr. Kevin K. Kumashiro

University of Illinois, Chicago

Dr. Jonathan H. X. Lee

San Francisco State University

Dr. Monirith Ly

Texas State University-San Marcos

Dr. Bic Ngo

University of Minnesota

Dr. Leakhena Nou

California State University, Long Beach

Dr. Isabelle Thuy Pelaud

San Francisco State University

Dr. Giang Pham

University of Massachusetts

Dr. Bounlieng Phommasouvanh

Minnesota Department of Education

Dr. Kalyani Rai

University of Wisconsin, Milwaukee

Dr. Soveacha Ros

Royal University of Phnom Penh

Dr. Nancy J. Smith-Hefner

Boston University

Dr. Christine Su

Ohio University

Dr. Loan Tran

University of California, Riverside

Dr. Tinou Tran

Alief Independent School District

Dr. Silvy Un

Frost Lake Elementary School

Dr. Terrence G. Wiley

Center for Applied Linguistics

Dr. Zha Blong Xiong

University of Minnesota 
Journal of Southeast Asian American Education and Advancement, Vol. 9 [2014], Iss. 1, Art. 7

Ya-The Two Leaders: One Wise and One Foolish

Ravy Lao

University of California, Santa Barbara

Thien-Huong Ninh

University of Southern California

Malaphone Phommasa

University of California, Santa Barbara

Alisia Tran

University of Minnesota

Anna H. Yang

University of Georgia
Minh Mai

University of Wisconsin-Madison

Hoa Nha Nguyen

Boston College

Vanna Som

Harvard University

Krissyvan Truong

Claremont Graduate University

Lesley Yang

University of Minnesota 